Pawet Skuczyński

\title{
Typy myśli krytycznej w prawoznawstwie Od krytyki poznania do walki o uznanie
}

\section{Wprowadzenie}

We współczesnej kulturze myślenie krytyczne jest nieodzownym elementem wielu jej obszarów. Myśli krytycznej nie należy jednak po prostu utożsamiać z postulatem krytycyzmu występującego na gruncie metodologii nauk. Pozostaje on w związku m.in. z takimi postulatami, jak poszukiwanie racji dostatecznej, uczciwość i rzetelność naukowa czy nieuznawanie autorytetów ${ }^{1}$. Ma on więc charakter powszechny i w znacznej mierze zdroworozsądkowy. Dotyczy wszystkich nauk, niezależnie od ich paradygmatu, a zatem tego, jak określają one swój przedmiot oraz jakie stosują metody.

Jednakże wśród dyscyplin naukowych występują również takie, których istotą jest myślenie krytyczne. Jeśli bowiem nauki podzielić ze względu na konstytuujące je interesy poznawcze, to można wyróżnić dyscypliny empiryczno-analityczne realizujące interes techniczny, historyczno-hermeneutyczne realizujące interes praktyczny oraz krytyczne nauki społeczne realizujące interes emancypacyjny. Polega on na tym, że wiedza o zasadach działania społeczeństwa i podmiotu ,wzbudza proces refleksji w świadomości tych, o których prawa te mówią"2. W konsekwencji wspomniana wiedza jest warunkiem możliwości odrzucenia takich zasad lub ich przekształcenia. W tym sensie praktyka społeczna staje się niezależna od zasad ją konstytuujących, a więc następuje jej emancypacja. Do nauk takich należą ekonomia, socjologia czy politologia.

Na tym tle nie jest jasne, czy i w jaki sposób myślenie krytyczne jest obecne w naukach prawnych. Wynika to z wielu przyczyn, spośród których dwie wydają się najważniejsze. Po pierwsze, nie jest rozstrzygnięty spór o autonomię metodologiczną prawoznawstwa oraz kontrowersja między naturalistami

\footnotetext{
1 Na gruncie nauk prawnych zob. przede wszystkim: M. Zieliński, Poznanie sqdowe a poznanie naukowe, Poznań 1979, s. 116 i n.

2 J. Habermas, Interesy konstytuujace poznanie, „Colloquia Communia” 1985, nr 2, s. 164.
} 
i antynaturalistami w jego ramach. Spór ten w znacznej mierze dotyczy zaliczenia nauk prawnych do jednej ze wskazanych wyżej grup dyscyplin: empiryczno-analitycznych lub historyczno-hermeneutycznych ${ }^{3}$. Wobec braku rozstrzygnięcia, zwolenników zyskuje teza o pluralizmie metodologicznym prawoznawstwa i uznaniu m.in. metod, takich jak analiza pojęć i hermeneutyka, za w równej mierze prawomocne ${ }^{4}$. W tej perspektywie stanowisko o naukach prawnych jako dyscyplinach krytycznych jak dotąd nie liczyło się, nie będąc łatwo przekładalnym na tezy metodologiczne. Po drugie, tradycja nauk prawnych, przede wszystkim w kulturze prawa stanowionego, polega na dogmatycznym opracowaniu materiału prawnego. Oznacza to, że przyjmują one teksty prawne jako dane, poddając je jedynie zabiegom interpretacyjnym i systematyzacyjnym. Warto zaznaczyć, że wyodrębnienie nauk dogmatycznych i przeciwstawienie ich naukom krytycznym jest wcześniejsze od podziału nauk na empiryczno-analityczne oraz historyczno-hermeneutyczne, który - najogólniej rzecz biorąc - jest konsekwencją sporu między pozytywistami i neokantystami o status humanistyki. Tymczasem już u Kanta prawo zaliczane jest, wraz z teologią i medycyną, do nauk dogmatycznych, określanych przez niego ironicznie jako fakultet wyższy i przeciwstawiane filozofii oraz przyrodoznawstwu, nazywanym fakultetem niższym. Nauki dogmatyczne nie tworzą tekstów będących przedmiotem ich zainteresowania, ani nie badają ich wiarygodności. Powiązane są również z procesami sprawowania władzy w społeczeństwie . W tym ujęciu dopuszczenie myślenia krytycznego w ich ramach spowodowałoby niemożność wypełniania przez nie ich społecznych funkcji.

Wszystko to powoduje, że myślenie krytyczne w naukach prawnych można określić jako marginalne. Wydaje się jednak, że jego znaczenie będzie wzrastać. Dotyczy to w szczególności Europy Środkowo-Wschodniej w obecnej sytuacji historycznej. Z jednej strony bowiem w sferze praktyki prawniczej coraz częściej występuje postawa określana $\mathrm{w}$ anglosaskiej kulturze prawnej jako prawniczy radykalizm (radical lawyering). Polega ona traktowaniu prawa jako środka zmian samego prawa oraz związanych z nim stosunków społecznych, w tym sposobu sprawowania władzy. Radykalni prawnicy przyjmuja jedynie takie sprawy oraz prowadzą je w taki strategiczny sposób, aby doprowadzić do zmiany społecznej: bądź przez ich nagłośnienie i stworzenie presji na parlament, bądź przez poszukiwanie uznania dla swoich argumentów, z reguły przez tych sędziów, którzy są aktywistycznie nastawieni. Prym w tej dziedzinie wiodą oczywiście organizacje zajmujące się ochroną praw człowieka, w szczególności zwalczające

3 L. Morawski, Główne problemy współczesnej filozofii prawa. Prawo w toku przemian, Warszawa 2000, s. 291 i n.

4 J. Stelmach, B. Brożek, Metody prawnicze. Logika-analiza-argumentacja-hermeneutyka, Kraków 2004, s. 36-37.

5 I. Kant, Spór fakultetów, Toruń 2003, s. 63 i n. 
dyskryminację. Radykalni prawnicy poszukują intelektualnych podstaw swoich działań nie w tradycyjnych doktrynach prawniczych, lecz właśnie w prawniczej myśli krytycznej.

Ponadto, poza sferą praktyki, nieco innych odcieni przybierają spory toczące się w ramach filozofii prawa. Dyscyplina ta ze swej istoty jest niedogmatycznie nastawioną częścią prawoznawstwa. Jednakże wraz ze stopniowym zwiększaniem jej związków z naukami prawnymi i rozluźnianiem powiązań z ogólną refleksją filozoficzną staje się ona sferą autorefleksji tych pierwszych. Ze względu na tego typu specjalizację oraz instytucjonalne osadzenie, jej przedmiotem staje się nie tyle klasyczny problem jedności wiedzy, lecz raczej jej społecznych funkcji ${ }^{6}$. Mogą być one dwojakiego rodzaju: legitymizacyjne lub krytyczne. Te pierwsze są typowe dla klasycznie rozumianych dogmatyk prawniczych. Są one jednak o tyle problematyczne, że prowadzą do instrumentalizacji filozofii, bowiem służy ona wówczas rzeczywistości, utrwalając panujące stosunki. Musi budzić to sprzeciw krytycznie nastawionej części prawników i filozofów prawa.

Celem niniejszych rozważań jest niepretendujące do zupełności przedstawienie różnorodności myślenia krytycznego w prawie. Tak jak nie istnieje jeden powszechnie przyjmowany model doktryny prawniczej, tak też myślenie krytyczne w naukach prawnych cechuje różnorodność. Podkreślenie owej różnorodności jest ważne m.in. dlatego, że w obiegowych opiniach myślenie krytyczne jest często utożsamiane np. jedynie z postmodernizmem i filozofią radykalnego zerwania. Takiemu poglądowi należy się przeciwstawić chociażby po to, aby unaocznić fakt, że myślenie krytyczne jest filozoficznie znacznie bogatsze i stanowi poważną ofertę intelektualną.

Oczywiście w tym opracowaniu możliwe jest w gruncie rzeczy jedynie wyliczenie, a nie kompleksowe omówienie ich podstawowych tez i przyjmowanych założeń. Należy również zastrzec, że mowa jest tu o typach myślenia krytycznego, a więc podział ten nie jest rozłączny i opiera się na idealizacji. Jest to zastrzeżenie tym bardziej istotne, że co do wielu ujęć myśli krytycznej można spierać się o ich przynależność do takiego lub innego wyodrębnionego typu.

\section{Kantowski konstruktywizm - krytyka poznania}

W związku z szerokim ujęciem myślenia krytycznego, w niniejszych rozważaniach w pierwszej kolejności należy wspomnieć o krytycznej filozofii transcendentalnej I. Kanta. Jest to o tyle uzasadnione, że w intencji samego jej twórcy filozofia ta była wymierzona przeciwko tradycyjnej metafizyce i oferowała intelektualne narzędzia do oceny, co w tradycji tej miało charakter wiedzy, a co było wykroczeniem poza warunki poznania. Należy podkreślić, że okres krytyczny

${ }^{6}$ Zob. J. Habermas, The idea of the university: Learning processes, „New German Critique” 1987, no. 41, s. 16. 
w twórczości Kanta oznacza odejście od rozumienia filozofii jako analizy , a więc zmianę jej stosunku do nauki. Jej podstawowym zadaniem w tym ujęciu nie jest budowanie pojęciowej wiedzy o bycie, lecz krytyka procesów poznawczych zmierzających do owej wiedzy.

Jednocześnie Kant szuka podstaw dla krytyki poznania, a więc jej uprawomocnienia. Cel ten realizuje poprzez badanie formy poznania, a nie jego treści ${ }^{8}$. Forma ta polega na tym, że podmiot konstruuje poznawany przedmiot przy pomocy apriorycznych pojęć i kategorii rozumu, pozwalających usystematyzować dane pochodzące ze zmysłów. Tu znajduje swoje źródło pojęcie ważności (Geltung), które dostarcza zbioru formalnych kryteriów niezbędnych do krytyki poszczególnych aktów poznania. Jeśli dany akt pomyślnie przejdzie taki krytyczny test, wiedzę będącą jego efektem należy uznać za prawomocną.

Również w filozofii praktycznej, w tym w filozofii prawa, filozofia ta dostarcza narzędzi krytyki. Wiążą się one przede wszystkim z kategorią wolności, odmienne rozumianą na gruncie rozważań Kanta o moralności, a inaczej na gruncie jego filozofii prawa. W obydwu jednak przypadkach również opiera się na formalnych kryteriach oceny, jakie działanie będzie zgodne z wolnością: w przypadku moralności - takie, które jest działaniem z obowiązku według poddającej się uniwersalizacji reguły; w przypadku prawa natomiast - takie, które jest zgodne z regułami w równym stopniu gwarantującymi wolność każdemu?

Kantowski krytycyzm jest więc ściśle związany z ideą wolności, rozumianą przede wszystkim jako autonomia rozumu. Polega ona na samodzielnym i uwarunkowanym jedynie przez kategorie samego rozumu posługiwaniu się nim przez podmiot. Jest to więc również filozofia ze swej istoty oświeceniowa i jako taka obecna jest w późniejszych etapach rozwoju myśli krytycznej. Można powiedzieć, że późniejsza myśl krytyczna m.in. poszukiwała różnych, przeoczonych przez Kanta, przyczyn nieautonomiczności rozumu i sposobów jego emancypacji, dokonując radykalizacji jego projektu filozofii krytycznej.

Natomiast projekt filozofii krytycznej nieradykalnej, ograniczonej do zagadnień poznawczych, był kontynuowany przez neokantystów. Taki miękki krytycyzm czy krytyczny konstruktywizm można przykładowo przypisać Hansowi Kelsenowi, szczególnie w najwcześniejszym okresie jego twórczości. Wiąże się to, co prawda, z koniecznością przyjęcia niestandardowej interpretacji, według której podstawowym celem czystej nauki prawa, opierającej się na konsekwentnym rozdzieleniu sfer bytu i powinności, jest reforma nauk prawnych, a nie budowa koncepcji systemu prawnego i obowiązywania prawa, które okazują się wówczas jedynie środkami do osiągnięcia tego zasadniczego celu. Wymaga to przede wszystkim przyjęcia interpretacji normy podstawowej nie jako uzasadnienia

7 O. Höffe, Immanuel Kant, Warszawa 2003, s. 32.

8 Zob. J. Woleński, Epistemologia. Poznanie - prawda - wiedza-realizm, Warszawa 2005, s. 89.

9 Zob. M. Żelazny, Idea wolności w filozofii Kanta, Toruń 1993, rozdz. 3 i 5. 
normatywności prawa, lecz jako idei regulatywnej nauk prawnych, określającej ideał systematyzacji materiału prawnego zgodnie $\mathrm{z}$ dynamicznymi powiązaniami między normami prawnymi. W konsekwencji Kelsen jawi się jako filozof nauki, który dokonuje krytyki nauk prawnych i jej oczyszczenia np. z wpływów psychologizmu ${ }^{10}$.

\section{Filozofia marksowska - krytyka społeczna}

Typowym przykładem radykalizacji myśli krytycznej i przejścia od krytyki poznania do krytyki społecznej jest myśl K. Marksa. Należy przede wszystkim zaznaczyć, że oryginalna filozofia marksowska nie jest tożsama z późniejszymi jej wariantami, w szczególności tzw. marksizmem wschodnim, czyli po prostu marksizmem-leninizmem. W pierwszym przypadku można bowiem mówić o myśli krytycznej, w drugim natomiast ta sama teoria uległa dogmatyzacji i została włączona w mechanizmy sprawowania władzy.

Niezmiernie istotnym elementem filozofii marksowskiej, którą często uważa się za dającą początek rozwoju filozofii krytycznej w ogóle, jest słynna teza, że zadaniem filozofii jest zmienianie świata, a nie jego opisywanie. Jeśli bowiem koncentruje się ona na tym ostatnim, to w konsekwencji może być ona każdorazowo jedynie odzwierciedleniem istniejącego stanu rzeczy. Stan ten jednak podlega historycznym zmianom i jest przedmiotem interesów różnych grup społecznych, w szczególności największych z nich, których konflikt każdorazowo determinuje strukturę społeczną, czyli po prostu klas społecznych. W takiej sytuacji filozofia, ograniczając się jedynie do opisu świata niezależnie od własnych intencji, głosi tezy leżące w interesie tej klasy, której zależy na utrzymaniu społecznego status quo. To wyklucza jej rzeczywistą autonomię i kierowanie się wyłącznie prawdą.

Kluczowe w tym zakresie jest pojęcie ideologii, przez Marksa rozumianej jako fałszywa świadomość. Polega ona na tym, że treść świadomości danego podmiotu co do zasady w sposób dla niego nieuświadomiony jest zdeterminowana przez interes społeczny grupy, do której on przynależy. W związku z tym nie może być on autonomicznym podmiotem. Wiąże się z tym rozróżnienie bazy ekonomicznej społeczeństwa i kulturowej nadbudowy podlegającej ideologizacji. W odniesieniu do konkretnej epoki - współczesnego Marksowi kapitalizmu uznawał on, że elementem stosunków społecznych nadającym kulturze ideologiczną formę jest własność, decydująca o pozycji społecznej jednostki w ramach procesów produkcji, a jej konsekwencją w sferze kultury jest m.in. zapośredniczenie stosunków społecznych przez rzeczy - towary wytwarzane w jej ramach (fetyszyzm towarowy).

${ }^{10}$ S. L. Paulson, Zachowujac czysta teorie prawa: norma podstawowa jako idea regulatywna, Warszawa 2013, s. 23. Zob. także: S. L. Paulson, Hans Kelsen's earliest legal theory: Critical constructivism, „The Modern Law Review” 1996, no. 59, s. 797 i n. 
Przedmiotem krytyki w omawianym ujęciu są więc przede wszystkim stosunki społeczne, które uniemożliwiają urzeczywistnienie prawdziwej wolności jednostek, poprzez uwolnienie podmiotu od ideologii. Nie ma, zdaniem Marksa, innej drogi do osiagniecia celu, jakim jest prawdziwie wolne społeczeństwo, niż radykalna zmiana społeczna. W tym miejscu oczywiście zaczyna się najsłabsze ogniowo jego filozofii, które jednocześnie zostało wykorzystane jako polityczna doktryna. Uświadomienie ideologicznego charakteru własnych przekonań miało być bowiem możliwe tylko w ramach jednej grupy społecznej, tj. proletariatu, która następnie miała dokonać zmiany społecznej $\mathrm{w}$ drodze rewolucji.

Zarówno założenia filozofii marksowskiej, jak i dzieje marksizmu jako instrumentu przemocy wyraźnie wskazują na bardzo istotną cechę krytyki społecznej, czyli jej refleksyjność. Oznacza to, że jeśli nie ma ona stać się swym przeciwieństwem, a więc ideologią, to jej warunkiem jest samoodnoszenie. Autentyczna myśl krytyczna musi więc, po pierwsze, spełniać wszelkie wymagania, które stawia przed innymi przejawami kultury, a po drugie, nieustannie reagować na zmiany przedmiotu krytyki, w tym przede wszystkim na uwzględnienie jej samej. Innymi słowy, refleksyjność oznacza włączenie do myśli krytycznej nie tylko jej logicznych konsekwencji, lecz także rzeczywistych skutków społecznych.

Warto również podkreślić, że mimo materialistycznego i historiozoficznego charakteru filozofii marksowskiej, a wiec zdawałoby się zupełnie innych treści niż w filozofii kantowskiej, między zwolennikami obydwu teorii toczyły się żywe dyskusje. Niektórzy neokantyści interpretowali filozofię marksowską jako rozwinięcie wybranych tez Kanta, „Etyka Kanta jest bowiem według marburczyków przede wszystkim e t y k ą w s p ó 1 n o t y, tak jak jest nią etycznie rozumiany socjalizm" "11. Jednakże zarzucali Marksowi uprzywilejowanie ekonomii i socjologii kosztem etyki. Obok społeczeństwa rozumianego empirycznie, w którym rządzą związki przyczynowe, wyróżniali bowiem etyczną ideę społeczeństwa jako wspólnoty złożonej z autonomicznych celów samych w sobie. Socjalizm, choć miał być przyczynowo efektem rozwoju społeczeństwa empirycznego, był pożądany z punktu widzenia społeczeństwa etycznego. Odrzucali go również ze względu na utożsamienie przez Marksa prawa i gospodarki, a to prawo jest według nich warunkiem logicznym gospodarki, jak również ze względu na zredukowanie wszystkiego do przyczynowości, z pominięciem roli idei prawnych i moralnych w ocenie stosunków gospodarczych ${ }^{12}$. Mimo to świadczyć to może o istnieniu związków między krytyką poznania i krytyką społeczną.

${ }^{11}$ M. Szyszkowska, Neokantyzm. Filozofia spoteczna wraz z filozofia prawa natury o zmiennej treści, Warszawa 1970, s. 67.

${ }^{12}$ Ibidem, s. 67-70, 80 i n. 


\section{Teoria krytyczna szkoły frankfurckiej - krytyka kultury}

Znaczenie szkoły frankfurckiej dla kształtowania myśli krytycznej jest nie do przecenienia. Krąg myślicieli takich jak M. Horkheimer, T. Adorno, H. Marcuse czy W. Benjamin określił samoświadomość myśli krytycznej, stanowiąc ważny punkt odniesienia także dla jej innych nurtów. Należy zaznaczyć, że mowa jest tutaj o tzw. pierwszym pokoleniu szkoły. Do kolejnych generacji zalicza się przede wszystkim takich autorów jak J. Habermas czy A. Honneth, którzy jednak prezentują nieco inny typ krytyki. Ponadto trzeba pamiętać, że szkoła frankfurcka to wielu autorów prezentujących często różne punkty widzenia. Rekonstrukcja kilku podzielanych przez nich idei opiera się więc zawsze na pewnym uproszczeniu. Najogólniej można jednak powiedzieć, że wspólnym dla nich mianownikiem jest przeniesienie krytyki w sferę kultury, a w konsekwencji jej dalsze urefleksyjnienie.

Jednym z założycielskich dla całej szkoły poglądów jest rozróżnienie teorii tradycyjnej i teorii krytycznej ${ }^{13}$. Teoria tradycyjna jest charakterystyczna dla nauki i skoncentrowana zawsze na opisie lub wyjaśnieniu określonego wycinka rzeczywistości. Jest ona więc elementem społecznego podziału pracy, jest określoną specjalizacją. W związku z tym jej społeczną funkcję stanowi użyteczność w systemie społecznym, rozumiana jako możliwość wykorzystania w praktyce. Jednakże sposoby tego wykorzystania nie należą do zakresu zainteresowania teorii tradycyjnej. W konsekwencji unika ona wartościowania rzeczywistości, do której się odnosi, a tym bardziej jej zmieniania. Przyczynia się więc ona do samozachowania istniejącego kształtu tej rzeczywistości.

W przeciwieństwie do tego, teoria krytyczna jest projektem intelektualnym, w sposób świadomy wyłamującym się ze społecznego podziału pracy i obejmującym całą rzeczywistość. Nie może więc być rozumiana jako jedna ze specjalizacji. Jednocześnie swoją funkcję społeczną pojmuje ona jako kwestionowanie i zmienianie istniejącej rzeczywistości społecznej, a więc nie unika wartościowania. Włącza bowiem do swego zakresu refleksję nad swoim własnym zastosowaniem i jako swój cel określa realizację interesu emancypacyjnego. W związku z tym „Celem teorii krytycznej jest emancypacja człowieka ze zniewalających go stosunków - rozumna organizacja ludzkiego życia"'14.

Teoria krytyczna jako typ myśli krytycznej podziela więc, np. z teorią Marksa, zainteresowanie emancypacją, czyli zmianą stosunków społecznych. Wywodzi się ona bowiem z doniosłego nie tylko etycznie, lecz również poznawczo założenia, że jednostki znajdujące się na szczytach hierarchii społecznej nie posiadają pełnej wiedzy o sposobie organizacji konkretnego społeczeństwa $\mathrm{i}$ w związku $\mathrm{z}$ tym nie są też zainteresowane jego zmianą. Im

${ }^{13}$ M. Horkeimer, Teoria tradycyjna a teoria krytyczna, „Colloquia Communia” 1983, nr 2, s. 39 i n.

${ }^{14}$ H. Walentowicz, Tęsknota za lepszym - historiozofia Maxa Horkeimera, Warszawa 2004, s. 24. 
dalej jednostka znajduje się od centrum społeczeństwa, tym lepszą posiada perspektywę zrozumienia mechanizmów społecznych i wolę ich zmiany. Zachowuje więc również zainteresowanie radykalną zmianą społeczną. Jednakże sceptycznie odnosi się do jej dokonania w formie rewolucji. Jak wskazuje sama nazwa, krytyka jest tu pojmowana jako przedsięwzięcie o charakterze teoretycznym, przy czym ze względu na swoje społeczne funkcje najbliżej tego celu jest filozofia ${ }^{15}$.

Stwierdzenie, że poznanie jest w stanie doprowadzić do skutków praktycznych w postaci zmiany społecznej, szkoła frankfurcka zawdzięcza w dużej mierze wpływom psychoanalizy. Podkreśla ona bowiem znaczenie samowiedzy o nieuświadomionych wcześniej przez podmiot mechanizmach. Dzięki niej może on posiadać nad nimi kontrolę, co - jak chcą zwolennicy teorii krytycznej - jest tożsame z uzyskaniem w stosunku do nich autonomii ${ }^{16}$. W skali społeczeństwa podobny skutek można uzyskać poprzez demaskowanie ideologii we wszelkich przejawach kultury. Dlatego też można powiedzieć, że ten typ myśli krytycznej jest przejściem od krytyki społecznej do krytyki kultury. Szczególną wagę w tym zakresie odgrywa krytyka sztuki, $\mathrm{w}$ tym funkcjonującej $\mathrm{w}$ ramach kultury popularnej i wprowadzonego przez T. Adorno pojęcia przemysłu kulturalnego ${ }^{17}$.

Najbardziej znaną krytyką w tym zakresie jest jednak krytyka racjonalności. Jest ona jednocześnie wyrazem dalszego urefleksyjnienia krytyki. Wychodzi się tu bowiem z założenia, że skoro przy pomocy rozumu należy zmieniać rzeczywistość, zaś jednocześnie rozum jest częścią rzeczywistości, odzwierciedla ją, a w konsekwencji traci autonomię na rzecz innych jej elementów, to krytykę należy zacząć właśnie od problematyki racjonalności. Stwierdzając, że w dziejach rozum urzeczywistnia się przede wszystkim jako narzędzie panowania nad przyrodą, a więc w technice, zauważa się, że w konsekwencji przybiera on specyficzną formę, którą określa się jako racjonalność instrumentalną. Jednakże forma ta nie ogranicza się do stosunków z naturą, lecz zostaje w kulturze uznana za uniwersalną i staje się wzorcowa zarówno dla racjonalności subiektywnej (poszczególnych podmiotów), jak i obiektywnej (sposobu zorganizowania społeczeństwa). Myślenie instrumentalne dominuje więc również stosunki międzyludzkie. W konsekwencji rozum staje się narzędziem panowania i uniemożliwia osiągnięcie autonomii, czyli emancypację $^{18}$. Problematyzacja roszczeń do uniwersalności różnych ujęć racjonalności jest kluczowa w rozwoju myśli krytycznej.

${ }^{15}$ Zob. M. Horkheimer, Społeczna funkcja filozofii, [w:] idem, Społeczna funkcja filozofii. Wybór pism, Warszawa 1987, s. 226-227.

${ }^{16}$ A. Szahaj, Teoria krytyczna szkoty frankfurckiej, Warszawa 2008, s. 10-11.

${ }^{17}$ Zob. T. W. Adorno, M. Horkheimer, Przemyst kulturalny. Oświecenie jako masowe oszustwo, [w:] iidem, Dialektyka oświecenia. Fragmenty filozoficzne, Warszawa 2010, s. 123 i n.

${ }^{18}$ Zob. M. Hokheimer, Krytyka instrumentalnego rozumu, Warszawa 2007. 


\section{Etyka dyskursu - jedność krytyki}

Ambitne zadanie podsumowania dorobku myśli krytycznej i rozwiązania niektórych z jej aporii przypadło kolejnemu pokoleniu filozofów, wśród których należy przede wszystkim zwrócić uwagę na dwie postacie. Po pierwsze, chodzi o twórce tzw. transcendentalnej pragmatyki, K.-O. Apla, który podjął próbę transformacji myśli Kanta w duchu odpowiadającemu współczesnej filozofii. Po drugie, chodzi oczywiście o twórcę uniwersalnej pragmatyki, J. Habermasa, który podobne przedsięwzięcie zrealizował w odniesieniu do teorii krytycznej szkoły frankfurckiej. Choć więc ich filozofie różnią się w sposób znaczący, to można wskazać wspólne im tezy, które są jednocześnie charakterystyczne dla tego typu myśli krytycznej.

Przede wszystkim jest to odejście od filozofii świadomości, nurtu w filozofii rozwijanego od kartezjanizmu po fenomenologie, i uznanie za fundamentalne kategorii XX-wiecznej filozofii języka. W szczególności chodzi oczywiście o badanie procesów komunikacji i centralne dla nich pojęcie dyskursu. Dzięki niemu możliwe było przeniesienie krytyki na wyższy poziom i refleksja nad samą krytyką o większym stopniu abstrakcji. Wysiłki teoretyczne zostały bowiem skoncentrowane na krytyce wszelkiego rodzaju dyskursów, zarówno teoretycznych, jak i praktycznych, w zgodzie z założeniem o jedności rozumu. W konsekwencji rozróżnienie krytyki poznania, krytyki społecznej i krytyki kultury traci na znaczeniu. Są one traktowane jako różne dyskursy, które jednak muszą spełniać podobne normatywne kryteria.

Innym bardzo ważnym elementem tego typu myśli krytycznej jest poszukiwanie uprawomocnienia krytyki ${ }^{19}$. Główny problem dotychczasowej myśli krytycznej dotyczył bowiem podstaw krytyki, a więc, mówiąc w skrócie, zawierał się w pytaniu, czy w samej kulturze, będącej przedmiotem krytyki, istnieje jakiś punkt oparcia wolny od ideologii. Innymi słowy, czy wobec dominacji instrumentalizmu w sferze rozumu możliwa jest racjonalność, która nie miałaby takiego charakteru. W ramach omawianego typu myśli krytycznej odpowiedź na to pytanie jest twierdząca. Uprawomocnienie krytyki odbywa się tu poprzez odwołanie do struktury aktów mowy czy aktów komunikacji i wskazanie ich złożonego charakteru. Nie polegają one bowiem wyłącznie na przekazywaniu sensów, lecz również na wyrażaniu oczekiwania ich akceptacji przez innych uczestników komunikacji jako wypowiedzi prawdziwych, słusznych i szczerych (roszczenia ważnościowe). Uznanie tych roszczeń oznacza konsens, a jego brak - potrzebę dyskursu argumentacyjnego, w ramach którego uczestnicy będą wzajemnie problematyzować swoje twierdzenia i je uzasadniać. Przy spełnieniu proceduralnych warunków, takich jak wolność argumentujących, ich równość i brak przemocy, prędzej czy później dojdzie do konsensu między uczestnikami komunikacji.

${ }^{19}$ Zob. A. M. Kaniowski, Jürgen Habermas - metamorfozy teorii krytycznej, [w:] A. M. Kaniowski, A. Szahaj, Wokół teorii krytycznej Jürgena Habermasa, Warszawa 1987, s. 42 i n. 
Budowany jest więc pewien idealny model dyskursu. Opiera się on na zbiorze proceduralnych wymogów etycznych, które łącznie składają się na etykę dyskursu. Jednocześnie stanowią one kryteria racjonalności aktów komunikacji, które nie mają instrumentalnego charakteru. W konsekwencji formalna etyka dyskursu może stanowić narzędzie krytyki procesów komunikacji rzeczywiście mających miejsce w konkretnych społeczeństwach, a poprzez utożsamienie stosunków społecznych z aktami komunikacji - również samych społeczeństw. Etyka ta jest uniwersalna, a więc pozwala na krytykę wszelkiego rodzaju dyskursów, niezależnie od okoliczności kulturowych i historycznych.

Należy zaznaczyć, że recepcja tego typu myśli krytycznej w prawoznawstwie nie jest oczywista. $Z$ reguły bowiem tzw. teorie dyskursu prawniczego koncentrują się na zastosowaniu etyki dyskursu do aktów stosowania prawa. W konsekwencji ich przedmiotem jest raczej racjonalność tych aktów, a nie samego prawa, choć treść np. wyroku sądowego w oczywisty sposób musi odpowiadać ustawie ${ }^{20}$. Nie są więc jednak wykorzystywane do krytyki prawa, a więc i społeczeństwa, w którym ono obowiązuje. Dzieje się tak w znacznej mierze wbrew intencji samych filozofów należących do tego typu myśli krytycznej, jak np. w przypadku J. Habermasa, którego intencje krytyczne są jasne, a który w konsekwencji samodzielnie taką krytykę podją $2^{21}$.

\section{Postmodernizm - radykalizacja krytyki}

Innym typem współczesnej myśli krytycznej jest niewątpliwie postmodernizm, rozumiany tu jako nurt filozoficzny, a nie etap w rozwoju późnokapitalistycznych społeczeństw. Jako taki jest związany z myślicielami z frankofońskiego kręgu, takimi jak J. F. Lyotard, M. Foucalt czy J. Derrida. Niewątpliwie należy on do myśli krytycznej, choć wyraźnie odcina się od tych jej typów, które uznaje za modernistyczne. Zarzuca im bowiem charakterystyczne dla filozofii nowoczesności błędy, a w konsekwencji przyczynienie się do wielkich klęsk ludzkości z początku XX w., w tym przede wszystkim do powstania totalitaryzmów. $Z$ tego względu należy go uznać za wyraz dążeń do zradykalizowania myśli krytycznej.

Widoczne jest to $\mathrm{w}$ głównej mierze w stosunku postmodernizmu do problemu uprawomocnienia krytyki. Wyklucza on tę możliwość z uwagi na odrzucenie możliwości ostatecznego uzasadnienia jakiejkolwiek teorii. Jednocześnie wskazuje, że wraz z twierdzeniem o możliwości uprawomocnienia krytyki zgłasza się roszczenie do jej uniwersalności. Według postmodernistów jest

${ }^{20}$ Zob. np. R. Alexy, Theorie der juristischen Argumentation. Die Theorie des rationalen Diskurses als Theorie der juristischen Begründung, Frankfurt am Main 1992.

${ }^{21}$ J. Habermas, Faktyczność i obowiazywanie. Teoria dyskursu wobec zagadnień prawa i demokratycznego państwa prawnego, Warszawa 2005. 
to błąd charakterystyczny dla myślenia, które co do zasady ma być przedmiotem krytyki. Zamiast uniwersalizmu etyki dyskursu proponują oni lokalność, a więc uznanie za uprawnione różnych punktów widzenia. Podkreślają więc pluralizm teorii. Nie może zatem dziwić, że sam postmodernizm stanowi nurt zróżnicowany wewnętrznie.

Poza odrzuceniem możliwości ostatecznego uprawomocnienia oraz uniwersalizmu, charakterystyczne dla postmodernistycznego typu krytyki jest poszukiwanie we współczesnych społeczeństwach związków między wiedzą a władzą. Ich istnienie jest jednym z powodów sceptycyzmu wobec roszczeń nauki do formułowania uniwersalnych prawd. Nauka daje się bowiem zaprzęgać w służbę władzy, legitymizując ją właśnie poprzez swój uniwersalizm, który jednocześnie uzasadnia jej wykorzystanie jako obiektywnie prawdziwej. Dzięki temu możliwe jest powstawanie nowych rodzajów władzy, takich jak np. władza dyscyplinarna w ujęciu M. Foucaulta, która może zaistnieć właśnie dzięki medycynie czy pedagogice, dostarczającym wzorców normalności i umożliwiającym ich egzekwowanie w ramach instytucji nowoczesnego społeczeństwa, takich jak szpitale czy szkoły. Władza ta pozostaje niezależna od poddanej prawnej i demokratycznej kontroli władzy suwerennej ${ }^{22}$. Istotą krytyki jest tutaj ujawnienie takich mechanizmów i umożliwienie wyzwolenia od nich, a także obnażenie nieadekwatności tradycyjnych pojęć prawnych do tego rodzaju wyzwań.

Podobną radykalizację krytyki zawiera chociażby teoria metanarracji, według której dla nowoczesności charakterystyczne jest istnienie takich teorii, które nie tylko zgłaszają roszczenie do uniwersalnej prawdziwości, lecz także do wyjaśnienia całości rzeczywistości i rządzących nią zasad, w tym również dostarczenia kryteriów rozstrzygających o prawdziwości innych teorii. Na mocy własnych założeń są więc one nieobalalne i szczególnie łatwo przekształcają się w ideologie oraz stają się źródłem opresji. Z reguły odwołują się one do takiej czy innej społecznej utopii i wyjaśniają rzeczywistość w perspektywie przyszłego porządku społecznego. Tym zresztą różnią się od przednowoczesnych mitologii, które co do zasady także stawały się opresyjnymi ideologiami, ale odwoływały się do rzeczywistego lub jedynie wyobrażonego zdarzenia z przeszłości, które fundowało porządek społeczny, jak np. akt stworzenia świata, umowa społeczna itp.

W naukach prawnych jednak, jak się wydaje, największą popularność zyskały postmodernistyczne koncepcje tekstu i znaczenia. W szczególności potencjał krytyczny zarówno na gruncie teorii prawa, jak i poszczególnych dogmatyk prawniczych ujawnia dekonstrukcja, która pozwala na odrzucenie tradycyjnego rozumienia pojęć prawnych jako uprzywilejowania pewnych znaczeń. Umożliwia ona również ujawnianie takich sytuacji, w których owo

${ }^{22}$ Zob. np. M. Foucalt, Nadzorować i karać. Narodziny więzienia, Warszawa 2013. 
uprzywilejowanie jest jednocześnie realizacją określonych interesów. Niewątpliwie może to mieć ożywczy wpływ na dyskusje toczące się w dogmatykach prawnych ${ }^{23}$. Należy podkreślić, że w związku z tym pozostaje jednak tendencja do nadmiernego rozszerzania granic postmodernizmu na gruncie prawoznawstwa, zarówno poprzez włączanie do niego takich typów myśli krytycznej, które należy uznać za odrębne, choć niewątpliwie pozostające pod jego wpływem (np. krytyczne studia nad prawem czy feministyczna teoria prawa), jak i takich, które być może przeciwstawiają się tradycyjnemu modelowi nauki prawa, ale trudno je zaliczyć do myśli krytycznej w ogóle (np. ekonomiczna analiza prawa) ${ }^{24}$.

\section{Krytyczne studia nad prawem - próba aplikacji}

Ruch krytycznych studiów nad prawem (Critical Legal Studies Movement - CLS) powstał pod koniec lat 70. XX w. w Stanach Zjednoczonych i w ówczesnej formie swoje apogeum osiągnął w kolejnej dekadzie. Był on wytworem amerykańskiej myśli prawniczej, której konserwatyzm starał się przełamać. Z tego względu w znacznej mierze abstrahował od teorii filozoficznych, choć nie wypierał się swej lewicowej tożsamości. Nie może to dziwić, ponieważ jednym z głównych celów ruchu było ujawnienie związków między nauką prawa a polityką.

Według programowych sformułowań R. Ungera, prawo w ujęciu CLS jest instrumentem polityki i opiera się na ideologiach, co mistyfikuje poprzez charakterystyczne dla klasycznej myśli prawnej założenia formalizmu i obiektywizmu. Przez formalizm rozumie się „wiarę w możliwość stworzenia dedukcyjnej czy quasi-dedukcyjnej metody, pozwalającej na jednoznaczne rozwiązanie konkretnych problemów decyzji prawnej"25, co ma stanowić o wyższości prawa nad sporami filozoficznymi czy politycznymi, które w przeciwieństwie do argumentacji prawnej - mają charakter ideologiczny. Natomiast obiektywizm jest

wiarą, że autorytatywny materiał prawny - system ustaw, orzeczeń sądowych i przyjętych idei prawnych - zawiera w sobie i ustanawia możliwy do obrony schemat społeczności ludzkiej [...]. Prawa nie są jedynie pochodną przypadkowych walk o władzę lub nacisków pozbawionych prawomocnego autorytetu ${ }^{26}$.

${ }^{23}$ Zob. A. Sulikowski, Derridiańska koncepcja prawa, „Zeszyty Naukowe Wałbrzyskiej Wyższej Szkoły Zarządzania i Przedsiębiorczości” 2007, nr 10, s. 166 i n.; A. Sulikowski, O możliwościach postmodernizacji nauki prawa konstytucyjnego, „Państwo i Prawo” 2010, nr 12, s. 3 i n.

${ }^{24}$ G. Minda, Postmodern Legal Movements: Law and Jurisprudence at Century's End, New York-London 1995.

${ }^{25}$ R. M. Unger, Ruch studiów krytycznych nad prawem, Warszawa 2005, s. 1.

${ }^{26}$ Ibidem, s. 2-3. 
W rzeczywistości jednak, według krytyków z CLS, taki „schemat społeczności ludzkiej” zawarty w prawie nie istnieje. Jest on tylko bezpodstawnie przyjmowanym założeniem, które pozwala przy pomocy formalistycznej metody podporządkowywać wykładnię prawa i akty stosowania prawa jednej wizji społeczeństwa przy pomocy formalistycznych metod. Przykładowo, można wskazać na rozważania D. Kennedy’ego - jednego z czołowych przedstawicieli CLS - dotyczące sporu między zwolennikami regulacji prawa prywatnego przy pomocy ścisłych reguł oraz przy pomocy elastycznych standardów, np. klauzul generalnych, mówiąc językiem typowym dla kultury prawa stanowionego. Spór ten na pierwszy rzut oka ma charakter sporu o zakres zastosowania formalistycznej metody, jednakże według Kennedy’ego każdemu sposobowi regulacji można przyporządkować pewne założenia antropologiczne, etyczne i polityczne. Regulacja przy pomocy ścisłych reguł odpowiada założeniom indywidualizmu, etyki polegania na sobie i liberalizmu, natomiast stosowanie standardów i klauzul generalnych to wspólnotowość, etyka troski i komunitaryzm. Spierając się o zakres formalizmu, prawnicy w gruncie rzeczy spierają się o wizję społeczeństwa. Ukrywają to jednak i w ten sposób doprowadzają do ideologizacji nauk prawnych ${ }^{27}$.

Ruch krytycznych studiów nad prawem jest więc w znacznej mierze zorientowany na krytykę poszczególnych gałęzi prawa, instytucji prawnych czy nawet poszczególnych norm. Można powiedzieć, że w jego ramach dochodzi do specjalizacji i uprawiania krytyki na gruncie poszczególnych nauk prawnych, czemu towarzyszą próby budowania krytycznej teorii prawa. Należy jednak podkreślić, że zasięg CLS nie ogranicza się do tradycyjnych gałęzi prawa i obejmuje również krytykę obszarów leżących na obrzeżach prawoznawstwa. Dotyczy to w szczególności edukacji prawniczej oraz etyki zawodów prawniczych, których rola w reprodukcji ideologicznego charakteru prawa jest wyraźnie podkreślana ${ }^{28}$.

Choć ruch krytycznych studiów nad prawem wydawał się znacznej mierze zamkniętym etapem, w ostatnich latach można obserwować jego nową falę. Nie ma ona już tak bardzo amerykańskiego charakteru i obejmuje prawników z różnych kultur prawnych. Inny jest również kontekst społeczny i polityczny, a więc i szczegółowe problemy, które są przedmiotem jego zainteresowania. Składają się bowiem na niego chociażby kwestie ograniczania praw w związku z zagrożeniem terrorystycznym, odpowiedzialność za kryzys ekonomiczny i rozkład jego ciężarów itp. Jednocześnie założenia i zadania, jakie stawiają sobie autorzy z nim się identyfikujący, pozostaje podobny: krytyczne przemyślenie

${ }^{27}$ D. Kennedy, Form and substance in private law adjudication, „Harvard Law Review” 1976, no. 89, s. 1685 i n.

${ }^{28}$ D. Kennedy, Legal education and the reproduction of hierarchy, ,Journal of Legal Education" 1982, no. 32, s. 591 i n. 
relacji między prawem a polityką. Ta ostatnia jest tu jednak rozumiana szerzej niż w przypadku pierwszej fali CLS, tj. nie tylko jako polityka instytucjonalna, lecz jako wszelkie przejawy władzy, a więc to, co polityczne ${ }^{29}$.

\section{Feministyczna teoria prawa, krytyezna teoria rasowa - walka o uznanie}

Ostatnim typem myśli krytycznej obecnym w naukach prawnych, o którym należy tu wspomnieć, są różnego rodzaju wysiłki teoretyczne podejmowane z partykularnych punktów widzenia. Stawiają sobie one za cel emancypację różnych upośledzonych we współczesnych społeczeństwach grup. Wśród nich najbardziej znane są feministyczna teoria prawa (Feminist Legal Theory) oraz krytyczna teoria rasowa (Critical Race Theory). Charakterystyczne jest, że stanowią one próbę aplikacji myśli krytycznej o szerokim zasięgu do węższych i jednocześnie bardziej związanych z konkretnym kontekstem kulturowym i historycznym. $Z$ tego względu, podejmując próby realizacji interesu emancypacyjnego, wyraźnie wskazują, o emancypację jakiej grupy społecznej chodzi.

Krótko rekonstruując założenia feministycznej teorii prawa, nie należy jej po prostu utożsamiać z feminizmem jako takim. Należy jednak zaznaczyć, że podobnie jak w przypadku tego ostatniego, można mówić o wielości perspektyw w jego ramach. Podstawowy podział, jak się wydaje, przebiega między feminizmem liberalnym, koncentrującym się na formalnym równouprawnieniu, a feminizmem radykalnym, skupionym na usuwaniu kulturowych przejawów dominacji mężczyzn (określanej jako patriarchat). Idąc dalej, można jednak wskazać na jeszcze większe rozdrobnienie w ramach tego nurtu, który łączy kwestie kobiece z problemami mniejszości seksualnych, rasowych czy zagadnieniami ekologicznymi. W każdym przypadku dostrzega się bowiem różnice w występujących w praktyce problemach różnych grup kobiet, jednak zawsze powstają one na tej samej podstawie: jawnej bądź ukrytej dominacji.

Niezależnie od tego, która wersja feminizmu zostanie przyjęta, zagadnienia prawne odgrywają w jego ramach ważną rolę. Dlatego też feministyczną teorię prawa uważa się zazwyczaj za nurt w pewnej mierze odrębny. Polega on na dokonywaniu krytyki poszczególnych instytucji prawnych jako wprost lub w sposób ukryty dyskryminujących. Charakterystycznymi metodami krytyki jest bądź abstrakcyjne analizowanie założeń światopoglądowych, które leżą u podstaw poszczególnych instytucji czy norm prawnych, bądź jego przeciwieństwo - przedstawianie konkretnych przypadków złego stosowania prawa lub postępowania zgodnego z prawem, lecz upośledzającego kobiety w różnych aspektach życia. Przykładowymi obszarami krytyki są sfera gospodarcza (równość płac, dostępność awansów, urlopy macierzyńskie, molestowanie), edukacja

${ }^{29}$ Zob. M. Stone, I. Rua Wall, C. Douzinas, New Critical Legal Thinking. Law and the Political, New York 2012. 
i sport (koedukacja, segregacja w sporcie), polityka (brak reprezentacji, parytety wyborcze), małżeństwo, rodzina i ciało (przerywanie ciąży, rozwody, przemoc domowa i gwałt, opieka nad dziećmi) ${ }^{30}$.

Z kolei krytyczna teoria rasowa prezentuje podobny sposób myślenia w odniesieniu do relacji między białą większością a kolorowymi mniejszościami w krajach takich jak Stany Zjednoczone, a także w skali globalnej - relacji między państwami Afryki czy Azji a państwami Zachodu. Zakłada ona, że formalne równouprawnienie poszczególnych ras ludzkich nie gwarantuje rzeczywistej równości, w szczególności w sferze gospodarki czy polityki. W krytyce podlega głównie doktryna całkowitej neutralności rasowej w sferze publicznej (colorblindness), która - zdaniem zwolenników krytycznej teorii rasowej - prowadzi do osłabienia tożsamości poszczególnych grup. Przynależność do określonej rasy jest bowiem kwestią identyfikacji z określoną kulturą, a nie zagadnieniem biologicznym. $\mathrm{Z}$ tego względu ignorowanie wynikającej z przesłanek rasowych różnorodności ostatecznie prowadzi do uznania za jedynie istotny punktu widzenia białych. Tymczasem punkty widzenia poszczególnych mniejszości (voice of color), zaledwie od niedawna formalnie równouprawnionych, cechuje potencjał krytyczny, który może wiele wnieść do pojmowania sprawiedliwości społecznej¹.

Ogólną ramą teoretyczną podsumowującą te wysiłki jest teoria uznania, rozwijająca pojęcie uznania (Anerkennung), obecne m.in. już u Hegla. Wśród wielu propozycji teoretycznych $\mathrm{w}$ tym zakresie najbardziej popularna wydaje się myśl A. Honnetha, należącego do kolejnego pokolenia szkoły frankfurckiej. Najogólniej rzecz biorąc, podkreśla ona, że współczesny poziom uspołecznienia wymaga bardziej skomplikowanych mechanizmów integracji społeczeństwa niż np. w epoce konfliktu klasowego. Mechanizmem takim jest właśnie uznanie, które należy rozumieć jako zawierające zarówno elementy kognitywne (rozpoznania tożsamości innych osób), jak i wartościujące (ich pozytywnej akceptacji). Z normatywnego punktu widzenia uznanie powinno prowadzić do indywidualizacji, a więc coraz większego zakresu tożsamości społecznie uznawanych, jak również do inkluzji, czyli objęcia możliwością niezakłóconego kształtowania własnej tożsamości coraz większej części społeczeństwa.

Na gruncie tego ujęcia istnieją trzy typy uznania: miłość opierająca się na emocjonalnej trosce o drugą osobę i dająca poczucie wyjątkowości własnej osoby, uznanie prawne opierające się na kognitywnym szacunku i gwarantujące równość oraz estyma opierająca się na solidarności jednostek i dająca poczucie wyróżnienia $^{32}$. Dla myśli krytycznej w naukach prawnych oczywiście kluczowe

${ }^{30}$ Zob. N. Levit, R. R. M. Verchick, Feminist Legal Theory. A Primer, New York-London 2006.

${ }^{31}$ R. Delgado, J. Stefancic, Critical Race Theory: An Introduction, New York-London 2001, s. 6 i n. Zob. też: K. W. Crenshaw, Twenty years of critical race theory: Looking back to move forward, „Connecticut Law Review” 2011, no. 5, s. 1315 i n.

32 A. Modrzyk, Pomiędzy normatywizmem a realizmem. Od teorii uznania Axela Honnetha do radykalnie refleksyjnej krytyki społecznej, Kraków 2013, s. 47-52. 
jest uznanie prawne. Polega ono na rozpoznaniu różnych tożsamości poszczególnych grup społecznych i uwzględnienie ich w prawie. Jest to jednocześnie celem wysiłków poszczególnych partykularnych perspektyw krytycznych. Jednak propozycje odnoszące się do poszczególnych gałęzi prawa budowane w ten sposób nie są wolne od kontrowersji. Charakterystycznym przykładem w tym zakresie są spory wokół tzw. cultural defense w prawie karnym ${ }^{33}$.

\section{Podsumowanie}

Przedstawione wyżej typy myśli krytycznej jedynie w pewnej mierze stanowią jej ewolucję. Choć wzajemnie do siebie nawiązują oraz często stanowią odpowiedź na słabości jej poprzednich wersji, to nie można sformułować konkluzji, że dochodzi między nimi do zastępowania jednej przez drugą, a więc że jakiś typ myśli krytycznej uczynił poprzednie zbędnymi. Można natomiast powiedzieć, że dzieje myśli krytycznej - również jej słabości i upadki - tworzą pewną tradycję hermeneutyczną, co od teoretyka wymaga znajomości całego jej dorobku. Znajomość ta pozwala konfrontować ze sobą poszczególne perspektywy i budować dyskurs zwrotnie krytyczny, a więc jest ona jednocześnie miarą refleksyjności myśli krytycznej.

${ }^{33}$ Zob. B. Wojciechowski, Interkulturowe prawo karne. Filozoficzne podstawy karania $w$ wielokulturowych społeczeństwach demokratycznych, Torun 2009. Por. M. Dudek, Czy każda kultura zastuguje na obronę? Kilka watpliwości dotyczacych cultural defence i prawa karnego w dobie multikulturalizmu, „Archiwum Filozofii Prawa i Filozofii Społecznej” 2011, nr 2, s. 47 i n. 